\title{
Pentingnya olahraga selama pandemi COVID-19
}

\author{
Dyah Ayu Woro Setyaningrum \\ Departemen Patologi Anatomi, Fakultas Kedokteran Universitas Trisakti, Indonesia \\ Email: dyahayu94@trisakti.ac.id
}

Pada tahun 2019, tercatat penyebab kematian utama di dunia adalah penyakit tidak menular, dan ranking pertama adalah penyakit jantung iskemik dengan persentase $16 \%$ dari total kematian sedunia, disusul stroke sebanyak $11 \%$ dan PPOK menyumbang 6\%.(1) Saat ini dunia sedang berada ditengah-tengah krisis dengan skala yang sangat besar yang belum pernah terjadi sebelumnya di jaman modern ini, yaitu pandemi COVID-19 yang melanda ke seluruh penjuru dunia. Hingga tulisan ini dibuat per tanggal 14 Desember 2020 telah tercatat 70.8 juta kasus dan 1.6 juta kematian terkonfirmasi COVID-19.(2) Sementara penyakit-penyakit tidak menular yang disebutkan sebelumnya merupakan co-morbid yang penting terhadap keparahan dan outcome dari penderita COVID-19.

Penularan yang cepat dari virus SARS Cov2 ini membuat pembatasan pergerakan manusia di seluruh dunia - penjarakan fisik, bekerja, dan sekolah daring dari rumah - membawa beberapa konsekuensi akibat perubahan kebiasaan perilaku hidup aktif menjadi lebih santai atau sedentary behaviour. Kita saksikan beberapa orang di sekitar kita, dan mungkin kita juga termasuk yang mengalami peningkatan berat badan selama isolasi mandiri pada masa pandemi COVID-19 ini. $^{(3)}$ Studi pada anak usia sekolah menunjukkan peningkatan BMI (Body Mass Index) terjadi secara signifikan pada anak-anak yang libur dibandingkan mereka pada masa sekolah. Walaupun pengaturan makan dan olahraga selama sekolah masih dianggap belum ideal namun perbedaan BMI antara masa sekolah dan masa libur menunjukkan pentingnya pengaturan diet dan aktifitas fisik/olahraga. ${ }^{(4)}$

Data CDC (Centers for Disease Control and Prevention) 2020 menunjukkan bahwa prevalensi obesitas pada dewasa meningkat. ${ }^{(3)}$ Diperkirakan $22 \%$ penduduk dewasa mengalami kenaikan berat badan selama pandemik COVID-19 ini. ${ }^{(5)}$
Peningkatan berat badan ini akan menimbulkan peningkatan risiko penyakit sistem kardiovaskuler dan metabolik. Kondisi-kondisi tersebut perlu menjadi perhatian apalagi kasus COVID-19 secara global masih tinggi, khususnya karena banyaknya laporan yang menyatakan bahwa pasien COVID-19 dewasa dengan obesitas dilaporkan mengalami outcome yang lebih parah. (3) Bukan tidak mungkin pula efek yang sama dapat terjadi pada usia yang lebih muda bahkan anak-anak yang memang rentan.

Studi pada orang dewasa menunjukkan bahwa faktor risiko peningkatan berat badan selama isolasi mandiri pada masa pandemi ini dengan perubahan pola hidup sedentary adalah akibat kekurangan tidur (sleep inadequate), kebiasaan mengudap/mengemil setelah makan malam, kurangnya pengendalian diri terhadap makan, kebiasaan makan sebagai respon terhadap stres dan kurangnya aktifitas fisik termasuk olahraga. ${ }^{(5)}$ Oleh sebab itu, praktis rekomendasi yang tepat untuk mengurangi risiko kenaikan berat badan di masa karantina mandiri adalah pentingnya mendapatkan jumlah tidur yang adekuat, hindari mengudap/mengemil setelah makan malam, penerapan pengekangan/restriksi diet, ubah mekanisme mengatasi stres, dan pertahankan kebiasaan latihan fisik/olahraga. ${ }^{(5)}$

Latihan anaerobik maupun aerobik memiliki efek menguntungkan pada metabolisme lipid. Latihan anaerobik telah terbukti memiliki pengaruh positif pada profil lipid. Keuntungan yang diperoleh dari latihan fisik berasal dari peningkatan curah jantung dan peningkatan kemampuan otot yang bekerja dan memanfaatkan oksigen dari darah. ${ }^{(7)}$ Manfaat lain dari latihan fisik adalah efeknya pada peningkatan kadar kolesterol HDL dan penurunan trigliserid, yang keduanya berakibat pada penurunan resiko penyakit jantung dan pembuluh darah. Manfaat 
lain olahraga yang diperoleh adalah peningkatan sensitivitas insulin, peningkatan fungsi kognitif, peningkatan respons terhadap stres psikososial, serta pencegahan depresi. ${ }^{(7,8)}$ Manfaat-manfaat ini sungguh penting di masa pandemi COVID-19 ini, karena penurunan risiko penyakit kardiovaskuler dan metabolik tentunya akan menurunkan tingkat keparahan dari COVID-19 akibat adanya comorbid juga memperbaiki kualitas hidup pada umumnya. Olahraga rutin juga bermanfaat dalam memperbaiki kualitas tidur pada usia menengah dan dewasa tua, melindungi tubuh melawan COVID-19 dengan cara meningkatkan elemenelemen imunitas tertentu (khususnya olahraga aerobik) yang memicu mobilitas limfosit, dan menurunkan tingkat keparahan penyakit. ${ }^{(9)}$

Melihat pentingnya menjaga hidup sehat dan berbagai manfaat positif dari olahraga rutin, maka yang menjadi pertanyaan selanjutnya adalah, olahraga apa yang baik dan aman untuk dilakukan selama pandemi ini? Sementara penjarakan fisik dan isolasi mandiri masih banyak diperlukan untuk membatasi penyebaran virus SARS Cov2. Pesan yang perlu ditekankan dan diperhatikan adalah keseimbangan antara manfaat aktifitas fisik/ olahraga dan risiko terkena infeksi saat olahraga, jadi kewaspadaan terhadap transmisi virus SARS Cov-2 tetap dilakukan antara lain yaitu dengan tetap memberikan penjarakan fisik. ${ }^{(9)}$

Beberapa penelitian melaporkan bahwa olahraga dalam ruangan (indoor) lebih besar risiko tertular infeksi virus ini, seperti kondisi ruang tertutup, banyaknya orang yang berada dalam ruangan olahraga, makin mempermudah terjadinya transmisi. Sehingga sangat perlu protokol yang ketat dan tepat antara lain menghindari kontak fisik atau terlalu dekat dengan orang lain ataupun dengan benda-benda yang bisa terkontaminasi. ${ }^{(9)}$ Mempertimbangkan bahwa penularan COVID-19 dari manusia ke manusia melalui droplet maka banyak negara menggunakan patokan penjarakan fisik yang banyak diadopsi adalah 1.5meter antar orang. ${ }^{(10)}$ Namun, jarak ini hanya tepat untuk kondisi berdiam di tempat, sehingga tidak lagi sesuai untuk orang yang berjalan, berlari apalagi bersepeda. Dapat disimulasikan apabila ada beberapa pelari dengan jarak tertentu namun dalam satu jalur yang sama maka pelari paling belakang akan menjadi yang paling banyak berisiko terpapar droplet atau partikel kecil aerosol yang mengandung virus. ${ }^{(9)}$ Jadi sebenarnya paling aman adalah melakukan olahraga luar ruang sendirian, namun terkadang atau bahkan seringkali tak terhindarkan saat berolahraga di luar akan bertemu pula dengan orang lain yang berolah raga.

Jarak yang direkomendasikan adalah 5 meter untuk yang berolahraga jalan cepat, dan jarak 10 meter untuk olahraga lari dengan pertimbangan partikel kecil aerosol yang dikeluarkan oleh seseorang akan tersuspensi di udara selama beberapa saat, bahkan partikel yang sangat kecil dapat menempuh jarak hingga puluhan meter. ${ }^{(9)}$ Oleh karena itu, masih perlu banyak pertimbangan dan studi yang diperlukan untuk menganalisis faktor-faktor yang mempengaruhi pertimbangan jarak yang aman seperti arah dan kecepatan angin pada protokol olahraga di tempat terbuka.

WHO (World Health Organization) merekomendasikan latihan fisik selama 150300 menit dengan intensitas sedang atau 75-150 menit dengan intensitas berat, atau kombinasi diantara keduanya per minggu. Olahraga seperti ini dapat dilakukan di rumah walau tanpa bantuan alat sekalipun, bahkan di ruangan terbatas, bukan ruang olahraga ataupun di pusat kebugaran. Berikut beberapa tips supaya tetap aktif dan mengurangi perilaku santai (sedentary) yaitu mengambil waktu sesaat untuk beraktifitas fisik rutin tiap hari misal menari, bermain dengan anak, mengerjakan pekerjaan rumah sehari-hari seperti membersihkan rumah, atau berkebun. Prinsipnya adalah tetap beraktifitas fisik walaupun di rumah. Bisa juga melakukan olahraga sendiri di rumah dengan panduan kelas olahraga online yang banyak kita temui di YouTube. Aktifitas sederhana seperti jalan di tempat dalam jangka waktu tertentu, atau berjalan di sekeliling rumah, mengurangi banyak duduk dan berbaring, dan selalu mengusahakan untuk bangun berdiri setiap 30 menit dari posisi duduk. ${ }^{(11)}$

Seperti apakah olahraga intensitas sedang dan bagaimanakah yang intensitas berat? Contoh olahraga dengan intensitas sedang antara lain jalan cepat, tenis ganda dan bersepeda dengan kecepatan dibawah $16 \mathrm{~km} / \mathrm{jam}$. Sedangkan hiking, tennis tunggal, berenang beberapa kali putaran, loncat tali, dan bersepeda dengan kecepatan $16 \mathrm{~km} /$ jam atau lebih termasuk olahraga aerobik dengan intensitas berat. ${ }^{(6)}$ Sedangkan olahraga yang bisa dilakukan sendiri di rumah sekedar untuk menjaga 
tubuh tetap aktif misalnya dengan melakukan beberapa set gerakan olahraga rutin seperti angkat lutut ke siku yang berlawanan selama 1-2 menit dan diulang hingga 5 kali dengan diselingi istirahat 30-60 detik. Plank yaitu kedua lengan bawah di lantai menyangga tubuh dengan posisi siku tegak lurus dibawah bahu, pinggang ditahan setinggi kepala dan tahan posisi ini selama 20-30 detik atau lebih bila kuat dan diulang hingga 5 kali dengan diselingi istirahat 30-60 detik. Gerakan ekstensi ke belakang (back extension), squat dan berbagai gerakan latihan otot-otot ekstremitas, punggung, dan abdomen dapat dilakukan dengan repetisi, dan diakhiri dengan pendinginan yaitu duduk bersila di lantai dengan posisi seperti meditasi sehingga berguna untuk relaksasi dan menurunkan stres. ${ }^{(1)}$

Khusus mengenai pemakaian masker maka WHO tidak menyarankan memakai masker saat berolahraga karena masker dapat mengurangi kemampuan bernafas dengan nyaman, sedangkan keringat yang dihasilkan saat berolahraga menyebabkan masker menjadi basah dan lembab sehingga makin sulit bernafas, selain juga justru mendorong pertumbuhan mikroorganisme oportunis. Tindakan pencegahan yang paling penting saat berolahraga adalah menjaga jarak fisik sesuai rekomendasi. Olahraga sangatlah bermanfaat bagi kesehatan fisik maupun mental, namun pelaksanaannya dalam masa pandemi ini tetap harus dengan cara yang aman dan tepat untuk mengurangi masifnya penyebaran COVID-19. Saat tulisan ini selesai kami susun per tanggal 18 Desember 2020 menjadi sebanyak 72.8 kasus global terkonfirmasi, berarti ada kenaikan sekitar 2 juta kasus di dunia dalam 4 hari sejak tanggal 14 Desember 2020.(12) Salam sehat dan salam olahraga!

\section{REFERENSI}

1. WHO. The top 10 causes of death, 9 December 2020 [Internet]. World Health Organization; 2020 [cited 2020 Dec 14]. Available from: https://www. who.int/news-room/fact-sheets/detail/the-top-10causes-of-death

2. WHO. Coronavirus Disease (COVID-19) Dashboard, 14 Desember 2020 [Internet]. World Health Organization; 2020 [cited 2020 Dec 14]. Available from: https://covid19.who.int/

3. CDC. New CDC data finds adult obesity is increasing. CDC Newsroom [Internet]. Centers for Disease Control and Prevention; 2020 [cited 2020 Dec 14]. Available from: https://www.cdc. gov/media/releases/2020/s0917-adult-obesityincreasing.html
4. von Hippel PT, Powell B, Downey DB, et al. The effect of school on overweight in childhood: gain in body mass index during the school year and during summer vacation. Am J Public Health. 2007;97(4):696-702. doi: 10.2105/ AJPH.2005.080754

5. Zachary Z, Brianna F, Brianna L, et al. Selfquarantine and weight gain related risk factors during the COVID-19 pandemic. Obes Res Clin Pract. 2020 May-Jun;14(3):210-216. doi: 10.1016/j.orcp.2020.05.004

6. AHA. Recommendations for Physical Activity in Adults and Kids, 18 April 2018 [Internet]. American Heart Association; 2018 [cited 2020 Dec 16]. Available from: https://www.heart.org/ en/healthy-living/fitness/fitness-basics/aha-recsfor-physical-activity-in-adults

7. Patel H, Alkhawam H, Madanieh R, et al. Aerobic vs anaerobic exercise training effects on the cardiovascular system. World J Cardiol. 2017 Feb 26;9(2):134-138. doi: 10.4330/wjc.v9.i2.134

8. Nystoriak MA, Bhatnagar A. Cardiovascular Effects and Benefits of Exercise. Front Cardiovasc Med. 2018 Sep 28;5:135. doi: 10.3389/ fcvm.2018.00135

9. Dominski FH, Brandt R. Do the benefits of exercise in indoor and outdoor environments during the COVID-19 pandemic outweigh the risks of infection? Sport Sci Health. 2020 Jul 17:16. doi: 10.1007/s11332-020-00673-z. Epub ahead of print. Erratum in: Sport Sci Health. 2020 Aug 17::1. PMID: 32837566; PMCID: PMC7366884.

10. Lai CC, Shih TP, Ko WC, et al. Severe acute respiratory syndrome coronavirus 2 (SARS-CoV-2) and coronavirus disease-2019 (COVID-19): The epidemic and the challenges. Int $\mathrm{J}$ Antimicrob Agents. 2020 Mar; 55(3):105924.

11. WHO. Stay physically active during selfquarantine [Internet]. World Health Organization Regional Office for Europe; 2020 [cited 2020 Dec 18]. Available from: http://www.euro.who.int/en/ health-topics/health-emergencies/coronaviruscovid-19/novel-coronavirus-2019-ncov-technicalguidance/stay-physically-active-during-selfquarantine

12. WHO. Coronavirus Disease (COVID-19) Dashboard, 14 Desember 2020 [Internet]. World Health Organization; 2020 [cited 2020 Dec 18]. Available from: https:/covid19.who.int/ 